ROCZNIKI HUMANISTYCZNE

Tom LXIX, zeszyt $6-2021$

ZESZYT SPECJALNY

DOI: https://doi.org/10.18290/rh21696s-13

\title{
PANDEMIA I ŻYCIE RELIGIJNE. DYSKURS MEDIALNY I KATOLICY O KOMUNIKACJI KOŚCIOŁA KATOLICKIEGO W POLSCE*
}

\section{WPROWADZENIE}

Globalna pandemia COVID-19 wybiła społeczeństwa z ich naturalnego rytmu funkcjonowania i wywołała strumień zmian społecznych. Autorzy raportu Życie codzienne w czasach pandemii nazywają ją okresem reorganizacji codzienności, obejmującym - po pierwsze - przeobrażenia więzi (zwiększenie lub zmniejszenie samotności, oddalenie lub zbliżenie do innych, niedosyt lub nadmiar kontaktów), po drugie - przeobrażenia temporalnej organizacji codzienności, wreszcie po trzecie - nadmiar informacji i kontaktu z mediami, które wymuszają konieczność selektywnego trakto-

Dr hab. DARIUSZ WADOwSKI - adiunkt Katedry Kultury Medialnej w Instytucie Dziennikarstwa i Zarządzania Katolickiego Uniwersytetu Lubelskiego Jana Pawła II; adres do korespondencji: Al. Racławickie 14, 20-950 Lublin; e-mail: dariusz.wadowski@kul.pl; ORCID: https://orcid.org/ 0000-0001-8936-9557.

Dr hab. Justyna Szulich-KaluŻa, prof. KUL - dyrektor Instytutu Dziennikarstwa i Zarządzania Katolickiego Uniwersytetu Lubelskiego Jana Pawła II, Katedra Komunikacji Wizualnej i Nowych Mediów; adres do korespondencji: Al. Racławickie 14, 20-950 Lublin; e-mail: justyna.szulich-kaluza@kul.pl; ORCID: https://orcid.org/0000-0002-6845-168X.

${ }^{*} \mathrm{~W}$ niniejszym tekście omówiono wybrane wyniki badań zrealizowanych w ramach interdyscyplinarnego projektu badawczego finansowanego przez MNiSW (028/RID/2018/19): Кomunikacja Kościoła katolickiego w Polsce w okresie pandemii Covid-19, pod kierunkiem o. dr. hab. Mirosława Chmielewskiego CSsR. Całościowe opracowanie wyników ukaże się w publikacji książkowej: Mirosław Chmielewski CSsR, Małgorzata Nowak, ks. Piotr Stanisz, Justyna Szulich-Kałuża i Dariusz Wadowski, Komunikacja Kościoła katolickiego w Polsce w okresie pierwszej fali pandemii Covid-19. Raport z badań (w przygotowaniu). 
wania info- $\mathrm{i}$ mediasfery (Drozdowski $\mathrm{i}$ in. 23-24). W znaczący sposób przeobraziła także samą sferę komunikacji i mediów, w tym komunikacji religijnej, dotyczącej życia religijnego oraz mediów wyznaniowych.

Pandemia stała się wyzwaniem dla instytucji i grup religijnych na całym świecie. Kościoły i wspólnoty wyznaniowe, kierując się wskazaniami dotyczącymi bezpieczeństwa zdrowia publicznego, wdrażając niezbędne zmiany w obowiązujących zachowaniach religijnych, podejmowały różnego rodzaju działania, również o charakterze komunikacyjnym.

Semantyczna ewolucja słowa „komunikacja” świadczy o balansowaniu między dwiema zasadniczymi koncepcjami. Wywodzący się z języka łacińskiego termin (od łac. communicare) długo był kojarzony z uczestniczeniem w czymś, z łączeniem zarówno w wymiarze duchowym, jak i fizycznym. Idea „łączenia” stopniowo zacierała się na korzyść przekazywania komunikatów i sposobów przekazu za pomocą zróżnicowanych środków, doskonalących się wraz z rozwojem technik transportu i technologii, a także z użyciem mechanizmów relacji międzyosobowych i zbiorowych (Maigret 34).

Cele niniejszego sprawozdania są podwójne: po pierwsze - charakterystyka dyskursu mediów katolickich (portali internetowych i cyfrowych wydań ogólnopolskich tygodników) na temat instytucjonalnej komunikacji Kościoła katolickiego z okresu pierwszej fali epidemii COVID-19, a po drugie - ukazanie stosunku wiernych Kościoła katolickiego do oficjalnych komunikatów instytucji i podmiotów kościelnych publikowanych w związku $\mathrm{z}$ pandemią. Podjęta tematyka wpisuje się wyjątkowo aktualnie w nurt współczesnego dyskursu o skutecznej komunikacji w sytuacji kryzysu zdrowotnego, otwierając nowe interesujące pola interpretacyjne i problemowe.

\section{1. ŹRÓDŁA MATERIAŁU}

Opracowanie opiera się na materiale empirycznym o dwojakim charakterze. Wykorzystano przede wszystkim wyniki analizy dyskursu, obejmującej publikacje elektroniczne dotyczące komunikatów Kościoła katolickiego tematycznie związane $\mathrm{z}$ pandemią. Drugim rodzajem materiału były wyniki ogólnopolskiej ankiety internetowej, za której pomocą podjęto próbę zbadania opinii polskich katolików na temat komunikacji Kościoła w sytuacji pandemii.

Zasób materiałów stanowiących źródło danych dla analizy dyskursu zawierał publikacje medialne na temat oficjalnej komunikacji Kościoła katolickiego w Polsce, opublikowane na stronach internetowych pięciu kato- 
lickich portali w okresie od czasu ogłoszenia w Polsce stanu zagrożenia epidemicznego do końca września 2020 r. Uwzględniono następujące portale: aleteia.org.pl, deon.pl, fronda.pl, opoka.org.pl, wiara.pl. Ponadto analiza obejmowała publikacje $\mathrm{z}$ archiwum cyfrowych wydań trzech ogólnopolskich tygodników katolickich Gość Niedzielny (łącznie z dodatkami lokalnymi), Niedziela i Tygodnik Powszechny. Zastosowana metoda doboru źródeł polegała na tzw. procedurze „,z góry na dół” (top-down approach) punktem wyjścia było uniwersum możliwych przekazów, a następnie stopniowe zawężanie przedmiotowe i liczbowe zgromadzonych publikacji. Materiał wyselekcjonowano za pomocą listy słów kluczowych, w czego wyniku uzyskano bazę źródłową liczącą ogółem 234 publikacje dotyczące tematyki będącej przedmiotem zainteresowania, przy czym 99 publikacji pochodziło z katolickich portali internetowych, a 135 z internetowych wydań katolickich tygodników. Analiza dyskursu skoncentrowana na treści publikacji opierała się na wykorzystaniu klucza kategoryzacyjnego, w którym wzięto pod uwagę tytuły publikacji, tematy główne i uszczegółowione kategorie treściowe oraz towarzyszący tekstom materiał wizualny.

Drugim źródłem materiału wykorzystanego w niniejszym sprawozdaniu są, jak wspomniano, wyniki ogólnopolskich badań internetowych, przeprowadzonych w okresie od lutego do kwietnia 2021 r., a więc podczas tzw. trzeciej fali epidemii w Polsce. Celem tego sondażu było określenie sposobów odbioru komunikatów Kościoła katolickiego w Polsce dotyczących sytuacji pandemii i zasad zachowania bezpieczeństwa w obiektach kultu religijnego oraz podczas nabożeństw i uroczystości religijnych. W badaniach uczestniczyło ogółem 1058 dorosłych wiernych Kościoła rzymskokatolickiego mieszkających we wszystkich diecezjach kraju. Większość respondentów określała się jako osoby wierzące - stanowiły one $66,2 \%$ całej badanej próby. Drugą pod względem liczebności kategorię stanowiły osoby określające siebie jako głęboko wierzące $(29,4 \%)$. Takich, którzy uznali siebie za raczej niewierzących, było jedynie $3,2 \%$, a całkowicie niewierzących - 1,2\%. Pod względem autodeklaracji religijnej próba była więc raczej jednorodna, choć z pewnością nie odzwierciedla statystycznego rozkładu wierzących i niewierzących $\mathrm{w}$ polskim społeczeństwie ${ }^{1}$. Pozwalała jednak zrealizować główny cel badawczy, jakim było poznanie opinii właś-

${ }^{1}$ Według reprezentatywnych ogólnopolskich badań CBOS w 2020 r. odsetek respondentów określających siebie jako wierzących wynosił $83 \%$, głęboko wierzących $-8 \%$, a niewierzących 9\%. (Bożewicz 1-2). 
nie osób wierzących, mających kontakt z komunikatami instytucji kościelnych i katolickimi mediami.

\section{ANALIZA DYSKURSU}

Analiza dyskursu jest jedną z propozycji metodologii analizy złożonych materiałów badawczych. Dostarcza ogólnych ram pojęciowych na potrzeby badań ukierunkowanych problemowo (Wodak 12-13). Tradycyjnie i powszechnie dyskurs rozumiany jest jako działanie językowe w komunikacji pisemnej, wizualnej lub ustnej, werbalnej bądź niewerbalnej, podejmowane przez aktorów społecznych w konkretnym otoczeniu, określonym przez reguły, normy i konwencje społeczne (16). Analiza dyskursu w ogólnym znaczeniu opiera się na badaniu rozbudowanych aktów mowy i pisemnych tekstów, będących w relacji do ich kontekstów społecznych (Duszak i Fairclough 9).

\section{Ogólna charakterystyka dyskursu}

Analizowany dyskurs składa się z przekazów internetowych należących do dwóch klas jednostek tekstowych: (1) napisanych i skomponowanych specjalnie dla witryn www (teksty prymarnie internetowe) oraz (2) adaptowanych do witryn internetowych. Te ostatnie są rezultatem modyfikacji tekstów drukowanych w papierowych wydaniach tygodników na użytek sieci (teksty sekundarnie internetowe) (Wilkoń 42).

Od strony kompozycyjnej teksty elektroniczne cechuje niejednolity stopień wyróżnień graficznych poszczególnych komponentów. Ekspozycja miejsc strategicznych jest realizowana z wykorzystaniem podstawowych środków, do których należy zaliczyć: wyboldowanie tytułów, leadów i śródtytułów, zwiększony rozmiar czcionki, zastosowanie białych spacji oraz zmiany kroju czcionek. Zabiegiem uatrakcyjniającym przekaz jest jego zilustrowanie w postaci towarzyszących zdjęć. Jeśli chodzi o ocenę relacji między elementami tekstowymi i wizualnymi analizowanych publikacji i ich znaczenie komunikacyjne, to dostrzec należy zróżnicowanie proporcji w zależności od typu mediów. W tygodnikach materiały tekstowe nieznacznie przeważają ilościowo nad wizualnymi. Materiał $\mathrm{z}$ witryn portali katolickich cechuje natomiast nieco większa liczba ilustracji, towarzyszących poszczególnym tekstom.

Scharakteryzowany układ kompozycyjny tekstów korpusu z pewnością ułatwia „fragmentaryczne” rozpakowywanie treści przez użytkowników 
i usprawnia nawigację po tekście - zarówno pierwotną, jak i wtórną. Należy ją ocenić jako poprawną, ale niewyróżniającą się jakimiś elementami wpływającymi na memoryczność dyskursu, czyli formułę utrwalenia i zapamiętania wyróżnionych graficznie detali.

Analizy korpusu tekstów z uwzględnieniem zróżnicowania gatunkowego pozwalają na generalny wniosek o przewadze informacyjnych gatunków wypowiedzi dziennikarskiej nad publicystycznymi. Prawidłowość ta daje się wyraźnie zauważyć w przypadku portali (dominacja wzmianek, notatek informacyjnych, sprawozdań - 78). Realizują one podstawowe zadanie mediów, czyli powiadamianie i poszerzanie wiedzy na określony temat - w tym przypadku motywem przewodnim jest tematyka regulacji zachowań religijnych i życia religijnego w okresie pandemii COVID-19. Portal opoka.org.pl najbardziej wyróżnia się obecnością wypowiedzi o charakterze publicystycznym. W elektronicznych publikacjach ogólnopolskich tygodników dominują gatunki informacyjne (91) o zamiarze upowszechniania i utrwalania określonej wiedzy, choć odnotować należy relatywnie większą liczbę gatunków publicystycznych: artykułów i komentarzy (44), w których funkcja informacyjna jest połączona $\mathrm{z}$ interpretacją, wyjaśnianiem, poszukiwaniem kontekstów i kształtowaniem autorskich punktów widzenia.

\section{Tytuly publikacji ${ }^{2}$}

Teksty medialne zawierają tytuły nadające określone znaczenia przekazom i stanowiące ich punkty strategiczne: „każdy tekst ma swoje pozycje strategiczne, to znaczy takie, na których zwiększa się uwaga odbiorcy, jednocześnie pozycje te są celowo konstruowane przez nadawców" (Żydek-Bednarczuk 171). Tytuły poddane analizie dyskursywnej zostały ocenione ze względu na ich funkcje komunikacyjne, tj. orientującą i inicjacyjną w mniejszym zaś zakresie $\mathrm{z}$ uwzględnieniem kryterium składniowego, stylistycznego i leksykalnego.

W analizowanych publikacjach przeważały tytuły o charakterze informacyjnym nad tytułami publicystycznymi: $73 \%$ publikacji na portalach internetowych oraz $71 \%$ publikacji na stronach tygodników opatrzono tytułami informacyjnymi.

${ }^{2} \mathrm{~W}$ opracowaniu używane jest pojęcie „tytułu”, a nie „nagłówka” z uwagi na to, że w badanym materiale nie występują nadtytuły i podtytuły będące elementami nagłówków (Słownik terminologii medialnej 127). 
Tytuły pełnią też kilka funkcji, między innymi nominatywną - nazywają osoby, obiekty, wydarzenia, sytuacje będące przedmiotem publikacji, deskryptywną - przedstawiającą opis treści materiału w formie streszczenia konkluzji, i pragmatyczną - wyrażającą się w umiejętnym zainteresowaniu, skłonieniu do refleksji, do zajęcia określonego stanowiska oraz oddziaływaniu na odbiorców z zamiarem przekonania ich do wyrażanych treści (Gajda 83; Sadowska 403; Pawłowska 108). Dominującą pod względem częstotliwości funkcją tytułów, w jakie zaopatrzono analizowane materiały, była funkcja nominatywna - stwierdzono ją w przypadku $43 \%$ publikacji z portali i $62 \%$ publikacji z tygodników. Rzadziej autorzy, redaktorzy i wydawcy publikacji proponowali odbiorcom tytuły realizujące funkcję deskryptywną ( $41 \%$ publikacji na portalach i $24 \% \mathrm{w}$ tygodnikach), a najrzadziej funkcję pragmatyczną (15\% na portalach i 13\% w tygodnikach).

\section{Tematy glówne}

Tematami głównymi są wątki, które stanowią punkt wyjścia dla całej wypowiedzi dziennikarskiej i wokół których rozwijane są pozostałe, uszczegóławiające elementy treściowe o charakterze informacyjnym i publicystycznym. Do głównych tematów, którym poświęcono najwięcej uwagi i najobszerniejsze fragmenty publikacji, należy zaliczyć: omówienie treści oficjalnych dokumentów Kościoła katolickiego w Polsce dotyczących sytuacji pandemii, informacje o przypadkach zakażeń koronawirusem osób duchownych i parafian, instrukcje duszpasterskie sprawowania czynności liturgicznych i sakramentalnych oraz zagadnienia dotyczące istoty i znaczenia sprawowania praktyk religijnych.

Pierwszym istotnym składnikiem treściowym analizowanych publikacji medialnych było odniesienie, w formie cytatu, omówienia czy streszczenia, do treści oficjalnych dokumentów Kościoła katolickiego w Polsce dotyczących sytuacji pandemii. Głównymi podmiotami przygotowującymi owe dokumenty były Konferencja Episkopatu Polski (KEP) oraz poszczególne diecezje, stąd podczas analizy zastosowano podział na dokumenty KEP i dokumenty diecezjalne. Media elektroniczne uwzględnione w badaniach więcej miejsca poświęciły dokumentom diecezjalnym aniżeli komunikatom KEP. Ogółem odnotowano 45 publikacji odnoszących się do dokumentów diecezjalnych oraz 25 publikacji odnoszących się do dokumentów KEP, przy czym na stronach internetowych tygodników dominowały treści nawiązujące do dokumentów diecezjalnych. 
Kolejnym głównym tematem ogniskującym uwagę autorów/redaktorów/ wydawców analizowanych materiałów były informacje o zakażeniach koronawirusem. Najczęściej (ogółem 25 publikacji na portalach i stronach tygodników) dotyczyły one zakażeń w parafiach, następnie (13 publikacji) zakażeń we wspólnotach zakonnych i seminariach duchownych, oraz (12 publikacji) - zakażeń poszczególnych duchownych i biskupów.

Instrukcje duszpasterskie dotyczące sprawowania czynności liturgicznych i sakramentalnych $\mathrm{w}$ okresie pandemii to następny ważny temat analizowanych publikacjach elektronicznych. Najczęściej skupiały się one na kwestii sposobów sprawowania liturgii Triduum Paschalnego (ogółem 19 publikacji), instrukcji korzystania z transmisji mszy św. on-line (ogółem 10 publikacji), instrukcji udzielania sakramentów św. (ogółem 4 publikacje), instrukcji przyjmowania komunii św. (ogółem 2 publikacje) oraz instrukcji sprawowania liturgii pogrzebów (ogółem 2 publikacje). Wśród omawianych publikacji nie odnotowano ani jednej odnoszącej się do niezwykle istotnej sprawy, zwłaszcza w okresie Wielkiego Postu i Wielkanocy, zarówno dla wiernych, jak i duszpasterzy, a mianowicie wytycznych precyzujących korzystanie z sakramentu pokuty.

Ważnym tematem dla autorów/redaktorów/wydawców katolickich portali internetowych i stron poszczególnych tygodników katolickich okazały się także zagadnienia dotyczące istoty i znaczenia sprawowania praktyk religijnych. W tym obszarze tematycznym wyjaśniane były na przykład wątpliwości dotyczące Komunii św. w postaci duchowej i sakramentalnej, spowiedzi i żalu doskonałego za grzechy, praktyk Pierwszych Piątków Miesiąca czy też miejsc indywidualnych adoracji Najświętszego Sakramentu. Publikacji poruszających te wątki stwierdzono ogółem 23, przy czym zdecydowanie częściej występowały one na stronach tygodników niż na portalach katolickich.

Relatywnie mniej popularnym tematem okazało się negowanie pandemii i upowszechnianie różnorodnych interpretacji podważających jej istnienie i groźny przebieg. Tematyka ta pojawiała się na przykład w postaci stwierdzeń, że to wymysł rządów państw lub korporacji medialnych, dążących do zaburzenia życia społecznego, do laicyzowania społeczeństw, że to zaplanowany atak, którego celem jest utrudnienie przyjmowania sakramentów, że należy bagatelizować pandemię $\mathrm{w}$ zestawieniu z Boską wszechwładzą. Takich publikacji zauważono 11, przy czym niemal równie często występowały one na portalach katolickich, jak i na stronach tygodników.

Zaangażowanie on-line instytucji Kościoła i indywidualnego duchownych to następny temat główny podejmowany w analizowanych publikacjach, 
choć mniej eksponowany. Przede wszystkim opisywano aktywności różnych podmiotów kościelnych w obszarze nowych form „wirtualnego" duszpasterstwa i zazwyczaj pozytywnie je oceniano, choć akcentowano też, że działalność, o której mowa, winna być traktowana raczej jako uzupełnienie tradycyjnych modeli duszpasterskich. Wskazywano również na istniejące zróżnicowanie stopnia aktywności poszczególnych parafii, proboszczów, wikariuszów i zgromadzeń zakonnych. Publikacji poświęconych tym zagadnieniom było ogółem 10 .

Pozostałe wyróżnione tematy rzadziej się pojawiają i dotyczą między innymi nakazów reżimu sanitarnego w miejscach zbiorowego kultu (współpraca Kościoła z GIS, przestrzeganie dezynfekcji, zaleceń noszenia maseczek i zachowania dystansu społecznego) - stwierdzono 7 publikacji o tej tematyce; zachęt do modlitwy w intencji pokonania pandemii - 7 publikacji; różnych form wsparcia Kościoła w ograniczaniu skutków pandemii, przede wszystkim inicjatyw pomocowych i charytatywnych -5 publikacji.

\section{Szczególowe kategorie treściowe}

Przeprowadzona analiza dyskursu zmierzała również do wyodrębnienia szczegółowych kategorii treściowych, które współtowarzyszą tematom głównym ( $\mathrm{w}$ formie wzmianek, omówień, interpretacji i komentarzy publicystycznych). Wykaz wszystkich zidentyfikowanych treściowych kategorii szczegółowych obecnych w analizowanych publikacjach zawiera tabela 1 .

Tabela 1. Szczegółowe kategorie treściowe pojawiające się w analizowanych materiałach.

\begin{tabular}{|l|c|c|}
\hline TEMATY & PORTALE & TYGODNIKI \\
\hline $\begin{array}{l}\text { Zobowiązanie/zachęta do przestrzegania zasad sanitarnych w miejscach } \\
\text { kultu religijnego }\end{array}$ & 10 & - \\
\hline $\begin{array}{l}\text { Instrukcje dla aktywności duszpasterskiej i udzielania sakramentów } \\
\text { w czasie pandemii }\end{array}$ & 6 & - \\
\hline Zachęta do korzystania z dyspensy od uczestnictwa we mszy św. & 6 & 12 \\
\hline Zachęta do korzystania z transmisji on-line mszy św. i nabożeństw & 6 & - \\
\hline Rozporządzenia organów państwowych - stosunek pozytywny & 5 & 11 \\
\hline Zachęta do śpiewu Suplikacji & 5 & 7 \\
\hline Rozpowszechnianie teorii spiskowych & 5 & - \\
\hline
\end{tabular}




\begin{tabular}{|c|c|c|}
\hline Lekceważenie zasad sanitarnych w miejscach religijnych & 4 & - \\
\hline Podziękowanie wiernym za postawę odpowiedzialności i posłuszeństwa & 4 & - \\
\hline Zachęta do indywidualnych form kultu religijnego w świątyniach & 4 & 5 \\
\hline Zachęta do modlitwy w intencji oddalenia pandemii & 4 & 5 \\
\hline Podziękowanie służbom medycznym i sanitarnym & 3 & - \\
\hline Rekomendacje w sprawie celebracji Wielkiego Tygodnia & 3 & 12 \\
\hline $\begin{array}{l}\text { Instrukcje dla duszpasterzy w sprawie organizacji wirtualnych praktyk } \\
\text { religijnych }\end{array}$ & 2 & - \\
\hline Nadużycia prawa liturgicznego, kaznodzieje celebryci & 2 & - \\
\hline Rozporządzenia organów państwowych - stosunek negatywny & 2 & - \\
\hline Zalecenia dla przyjmowania sakramentów & 2 & 21 \\
\hline Pandemia czasem budowania i wzmacniania więzi rodzinnych & 1 & - \\
\hline Pandemia karą za grzechy, wyraz sprawiedliwości Bożej & 1 & - \\
\hline Przestrzeganie zasad sanitarnych w miejscach kultu religijnego & - & 10 \\
\hline $\begin{array}{l}\text { Formy duszpasterstwa indywidualnego, rozmowy duszpasterskie; litur- } \\
\text { giczne wytyczne dla kapłanów }\end{array}$ & - & 9 \\
\hline $\begin{array}{l}\text { Instrukcje transmisji online mszy św. i nabożeństw, informacje o trans- } \\
\text { misjach }\end{array}$ & - & 9 \\
\hline Zachęta do modlitwy za chorych & - & 9 \\
\hline Zmiany wraz z aktualizacjami w zakresie praktyk religijnych & - & 8 \\
\hline Apel o finansową pomoc dla chorych, medyków, szpitali & - & 5 \\
\hline $\begin{array}{l}\text { Odwołanie planowanych mszy św., odprawianie mszy św. bez udziału } \\
\text { wiernych w wyznaczonych intencjach }\end{array}$ & - & 5 \\
\hline Zachęta do modlitwy za służby medyczne & - & 5 \\
\hline Apel o zaangażowanie duszpasterskie kapłanów & - & 4 \\
\hline Niekorzystne skutki dyspensy od uczestnictwa w mszy św. & - & 4 \\
\hline Odwołanie inicjatyw duszpasterskich & - & 3 \\
\hline Rekomendacje na Wielki Post & - & 3 \\
\hline Instrukcje w sprawie organizacji pielgrzymek & - & 2 \\
\hline
\end{tabular}

Źródło: opracowanie własne. 
Zauważalne jest duże zróżnicowanie treści szczegółowych obecnych w analizowanych publikacjach. Wszystkie one dotyczą różnych aspektów życia religijnego poddanego określonym regulacjom w okresie pandemii, czemu towarzyszyły także różnego rodzaju napięcia i kontrowersje. Ich wyrazem może być chociażby to, iż część tych publikacji odnosi się do wspomnianych regulacji aprobująco spełniając rolę przekaziciela komunikatów podmiotów kościelnych i rządowych. Można powiedzieć, że odzwierciedlają one linię oficjalnej komunikacji. Z kolei inne materiały reprezentują stanowiska odmienne, bardziej krytyczne i zdystansowane wobec tej oficjalnej linii albo też po prostu skupiają się na faktach odstępstw od niej.

W powyższym zestawieniu można dostrzec odmienne rozłożenie akcentów na katolickich portalach i stronach internetowych tygodników, przejawiające się w postaci różnej częstotliwości podejmowania określonych zagadnień. Wśród treści obecnych na portalach internetowych dominowały (pod względem ilościowym) następujące: zachęty do przestrzegania zasad sanitarnych w obiektach kultu religijnego, instrukcje działań duszpasterskich i udzielania sakramentów, zachęty do korzystania $z$ dyspensy od uczestnictwa we mszy św., zachęty do korzystania z transmisji mszy św. i nabożeństw, pozytywne oceny zarządzeń władz państwowych, zachęty do śpiewu Suplikacji, a także różnego rodzaje teorie spiskowe. Natomiast w internetowych wydaniach tygodników dominowały następujące: zalecenia dotyczące przyjmowania sakramentów, zachęty do korzystania z dyspensy od uczestnictwa we mszy św., rekomendacje w sprawie celebracji Wielkiego Tygodnia, pozytywne oceny zarządzeń władz państwowych oraz ogólnie kwestie przestrzegania zasad sanitarnych w miejscach kultu religijnego.

Niektóre treści pojawiały się wyłącznie na portalach internetowych (i to kilkukrotnie), a były pomijane na stronach tygodników. Do takich tematów należą na przykład: zachęty dla wiernych do korzystania z internetowych transmisji mszy św., teorie spiskowe „wyjaśniające” pandemię, problem lekceważenia zasad sanitarnych przez wiernych czy też podziękowania za postawę odpowiedzialności i posłuszeństwa. Inne z kolei tematy pojawiały się niemal wyłącznie na stronach internetowych tygodników katolickich, ale nie zidentyfikowano ich w publikacjach na portalach katolickich. Jako przykłady możemy tu wymienić publikacje dotyczące różnych form duszpasterstwa indywidualnego, zachęty do modlitwy za chorych, apele o finansową pomoc dla chorych, medyków, szpitali czy też informacje o odwołaniu mszy św. lub ograniczeniu możliwości uczestnictwa w nich. 


\section{ODBIÓR KOMUNIKATÓW}

Bodźcem do powstawania omówionych powyżej materiałów internetowych w mediach katolickich były najczęściej oficjalne komunikaty instytucji państwowych i kościelnych. One też dostarczały tym materiałom kanwy treściowej. Tygodniki i portale katolickie pośredniczyły zatem w dostarczaniu wiernym informacji o różnego rodzaju zaleceniach dotyczących bezpieczeństwa w obiektach kultu religijnego, form sprawowania liturgii czy też ogólnie życia religijnego całej wspólnoty katolickiej w Polsce lub poszczególnych jej segmentów. Ogólnopolski sondaż internetowy zrealizowany wśród katolików zmierzał między innymi do określenia sposobów postrzegania i odbioru tych komunikatów.

Badania wykazały, że katolickie portale i strony internetowe w okresie pandemii są stosunkowo często wykorzystywane jako źródło informacji przez polskich katolików używających Internetu ${ }^{3}$. Prawie połowa badanych $(49,2 \%)$ korzysta ze stron internetowych poszczególnych mediów katolickich i prowadzonych przez nich profili na portalach społecznościowych regularnie, a prawie jedna trzecia $(31,4 \%)$ od czasu do czasu. Rzadziej natomiast badani korzystają z tradycyjnych czasopism katolickich: prawie co czwarta osoba $(23,2 \%)$ korzysta $\mathrm{z}$ nich regularnie, a co trzecia $(33,7 \%)$ od czasu do czasu. Jeszcze rzadziej respondenci słuchają katolickiego radia (13,0\% badanych deklaruje, że słucha go regularnie, a 29,7\% - od czasu do czasu) oraz oglądają katolicką telewizję $(8,8 \%$ badanych ogląda ją regularnie, a 32,7\% - od czasu do czasu). Mniej więcej dziesiąta część uczestników badań w ogóle nie korzysta z żadnych mediów katolickich: 10,7\% respondentów zadeklarowało, że w ogóle nie przegląda katolickich stron internetowych i profili na portalach społecznościowych. Co czwarta badana osoba $(24,4 \%)$ w ogóle nie korzysta $\mathrm{z}$ tradycyjnych papierowych czasopism katolickich, a częściej niż co trzecia - w ogóle nie słucha katolickiego radia $(37,0 \%)$ i nie ogląda katolickiej telewizji $(37,1 \%)$. Można zatem stwierdzić, że różnego rodzaju informacje i przekazy o charakterze publicystycznym trafiały do członków Kościoła katolickiego za pośrednictwem mediów cyfrowych.

W badaniach koncentrujących się wokół odbioru komunikatów Kościoła katolickiego dotyczących pandemii oraz związanych z nią zasad zachowania

\footnotetext{
${ }^{3}$ Ze względu na to, że przeprowadzone badanie miało formę sondażu internetowego, zakładamy, że jego wyniki odzwierciedlają zachowania i poglądy osób korzystających z Internetu, a niekoniecznie ogółu osób wierzących.
} 
bezpieczeństwa niezbędne było zidentyfikowanie źródeł, z których konkretnie respondenci czerpali tego typu informacje. Postawione $\mathrm{w}$ ankiecie internetowej pytania odnoszące się do tej tematyki były tak sformułowane, aby wyodrębnić pierwszą falę pandemii COVID-19 (pierwszy lockdown z wiosny 2020 r.) i kolejne, drugą i trzecią falę.

Podczas pierwszej fali najczęściej wybieranym źródłem, za którego pośrednictwem respondenci zapoznawali się z komunikatami dotyczącymi uczestnictwa w obrzędach i nabożeństwach religijnych, były media ogólnodostępne, takie jak telewizja, radio, Internet. Korzystanie z takich szerokoprofilowych mediów zadeklarowało $81,9 \%$ badanych. Prawie dwie trzecie respondentów $(64,9 \%)$ podczas pierwszej fali korzystało również z ogłoszeń parafialnych (odczytywanych, zamieszczanych na tablicach informacyjnych lub na stronach internetowych parafii lub kościoła). Co trzeci respondent $(33,1 \%)$ jako źródło informacji w pierwszej fali pandemii wskazywał strony internetowe instytucji i podmiotów kościelnych, takich jak Episkopat czy diecezje. Natomiast prawie co czwarty $(23,3 \%)$ deklarował korzystanie z mediów katolickich (czasopisma, telewizja, radio katolickie, czasopisma parafialne, internetowe portale katolickie). Zdecydowanie dominującymi źródłami informacji o regulacjach dotyczących uczestnictwa w nabożeństwach i obrzędach religijnych były zatem media ogólne oraz ogłoszenia w kościołach i parafiach. Media katolickie i katolickie portale odgrywały natomiast nieco mniejszą rolę.

Podczas drugiej i trzeciej fali pandemii (jesień 2020 r. - wiosna 2021 r.) poziom wykorzystania poszczególnych źródeł informacji nieco się zmienił, ale ich hierarchia pozostała podobna. Pozyskiwanie informacji za pośrednictwem ogólnodostępnych mediów (telewizji, radia, Internetu) z taką samą częstotliwością jak podczas pierwszej fali potwierdza $61,5 \%$ badanych. Podobny odsetek respondentów $(63,4 \%)$ deklaruje równie częste jak w pierwszej fali korzystanie $\mathrm{z}$ ogłoszeń parafialnych odczytywanych podczas mszy św. lub umieszczanych na tablicach informacyjnych czy stronach internetowych parafii. Połowa uczestników badań $(51,7 \%)$ tak samo często w obu falach korzystała z mediów katolickich: czasopism parafialnych, stron internetowych, katolickich telewizji i radia. Nieznacznie mniejszą częstotliwość $(48,5 \%)$ deklaracji równie częstego korzystania w obu falach pandemii odnotowujemy $\mathrm{w}$ przypadku stron internetowych oficjalnych podmiotów i instytucji kościelnych: Episkopatu i diecezji. Częściej niż co piąta badana osoba we wszystkich falach pandemii w ogóle nie korzystała z takich źródeł 
informacji, jak strony internetowe instytucji i podmiotów kościelnych $(28,4 \%)$ oraz media katolickie $(28,9 \%)$.

Uczestników badań poproszono także o wyrażenie ogólnej opinii o działaniach informacyjnych Kościoła katolickiego w Polsce i instytucji kościelnych, dotyczących ogólnie życia religijnego w sytuacji pandemii i ograniczeń z nią związanych.

Respondenci byli dość zróżnicowani w swoich poglądach na ten temat, ale generalnie dominowały opinie pozytywne. Co czwarta badana osoba $(25,4 \%)$ uważała, że Kościół i instytucje kościelne bardzo dobrze wywiązują się ze swoich zadań $\mathrm{w}$ tym zakresie, a ponad dwie piąte $(44,0 \%)$ - że wywiązują się z nich w stopniu raczej dobrym. Ogółem te pozytywne opinie stanowią $69,9 \%$ uczestników badań. Co szósty $(15,4 \%)$ respondent stwierdził jednak, że Kościół i instytucje kościelne raczej słabo wywiązują się z zadań informacyjnych, a co trzynasty $(7,9 \%)$ - że wywiązują się bardzo słabo. Opinie negatywne wyraziło ogółem 23,3\% badanych.

W innym pytaniu uczestnicy badań zostali poproszeni o ocenę języka komunikatów ze strony oficjalnych instytucji Kościoła katolickiego dotyczących sytuacji pandemii i zasad bezpieczeństwa. Komunikaty mogą być bowiem przekazywane $\mathrm{z}$ wykorzystaniem różnych środków językowych i charakteryzować się różnym stopniem skomplikowania. Wiele takich komunikatów publikowanych przez oficjalne instytucje Kościoła katolickiego, niekoniecznie dotyczących sytuacji pandemii, jest szeroko dyskutowanych w mediach, właśnie pod kątem zastosowanego języka.

Ponad dwie piąte badanych osób $(43,8 \%)$ stwierdziło, że język komunikatów oficjalnych instytucji Kościoła na temat pandemii jest jasny i w pełni zrozumiały dla przeciętnego odbiorcy, a ponad jedna trzecia $(34,7 \%)-$ że jest on dość jasny i raczej zrozumiały, choć nie dla każdego odbiorcy. Ogółem takie opinie o pozytywnym wydźwięku wyrażało $78,5 \%$ całej badanej próby. Co dziesiąty respondent $(10,6 \%)$ oceniał jednak język takich komunikatów jako niejasny i niezrozumiały dla przeciętnego odbiorcy. Co dwudziestej badanej osobie $(5,2 \%)$ trudno było natomiast wyrazić konkretną opinię na temat języka komunikatów.

\section{PODSUMOWANIE}

Przeprowadzona analiza dyskursu pokazała, że Kościół katolicki w sytuacji pierwszej fali zagrożenia epidemią COVID-19 wykazał się zauważalną 
aktywnością komunikacyjną ${ }^{4}$. Szybko pojawiły się oficjalne komunikaty regulujące zachowania religijne, między innymi takie jak: dyspensa od uczestnictwa w niedzielnej mszy św., propozycje indywidualnego przeżywania sakramentów, sposobu celebracji Wielkiego Postu i Triduum Paschalnego, pomoce duszpasterskie i poradniki korzystania $\mathrm{z}$ transmisji on-line.

W dyskursie medialnym obecnym na stronach internetowych popularnych portali katolickich i tygodników katolickich dominują trzy tematy - rozwijane w szeregu odmian uszczegółowionych:

- Dokumenty episkopalne i diecezjalne (klucz ich prezentowania jest następujący: umieszczenie pełnej wersji dokumentu, streszczenie najważniejszych treści, komentarze).

- Informacje o zakażeniach koronawirusem, które dotknęły różne podmioty życia religijnego: parafie, wspólnoty zakonne i seminaria duchowne, a także osoby indywidualne, pełniące różne funkcje instytucjonalne w Kościele. Przeważnie informacje te są traktowane jako potwierdzenie realnego zagrożenia koronawirusem, również w przestrzeni świątyń i zgromadzeń religijnych. Podawane precyzyjnie i wyczerpująco swoją formą wpisują się w podjęte starania o otwartą i przejrzystą oficjalną komunikację Kościoła katolickiego.

- Instrukcje duszpasterskie sprawowania czynności liturgicznych i sakramentalnych oraz wyjaśnienia dotyczące istoty i znaczenia praktyk religijnych $\mathrm{w}$ okresie pierwszej fali pandemii. Warto tu podkreślić, że przekazy te są często poparte autorytetem liturgistów oraz przedstawicieli środowisk akademickich. Tego typu materiały pokazują, że życie religijne w Polsce jest mocno skoncentrowane na pobożności sakramentalnoliturgicznej. Treści medialne o istocie i znaczeniu sakramentów (zwłaszcza np. Komunii św. duchowej) są obszerne treściowo, ale także charakteryzują się trudnym, teologicznym językiem.

Omówione wyniki ogólnopolskich badań internetowych wskazują z kolei, że polscy katolicy dość powszechnie czerpali informacje dotyczące zasad bezpieczeństwa i zmian w zakresie życia religijnego związanych ze stanem pandemii z Internetu, w tym z katolickich portali internetowych. Wprawdzie dominującym źródłem tych informacji były ogólnoprofilowe media, to jednak materiały dostępne w mediach katolickich mogły dostarczać informacji bardziej szczegółowych i - co ważne - interpretacji nowej sytuacji pandemicznej oraz zasad i zmian będących jej rezultatem. Ogólnie rzecz biorąc, polscy katolicy korzystający z Internetu stwierdzają, że Kościół katolicki

\footnotetext{
${ }^{4}$ Do podobnych wniosków dochodzi m.in. Marcin Gonera (88-99).
} 
w Polsce dobrze wywiązał się z zadań informacyjnych dotyczących życia religijnego w sytuacji pandemii. Język komunikatów również oceniono pozytywnie, co pozwala przypuszczać, że ich recepcja nie wiązała się z jakimiś większymi problemami.

\section{BIBLIOGRAFIA}

Bożewicz, Marta. Religijność Polaków w ostatnich 20 latach. Komunikat z badań nr 63/2020. CBOS, 2020.

Długosz, Piotr. Trauma pandemii COVID-19 w polskim społeczeństwie. CeDeWu, 2021.

Drozdowski, Rafał, Marek Krajewski, Małgorzata Kubacka, Ariel Modrzyk, Łukasz Rogowski, Przemysław Rura i Agnieszka Stamm. Życie codzienne wczasach pandemii. Raport z pierwszego etapu badań. Uniwersytet im. Adama Mickiewicza w Poznaniu. Wydział Socjologii, 2020, socjologia.amu.edu.pl/images/pliki $/ \mathrm{r} \% \mathrm{C} 3 \% \mathrm{~B} 3 \% \mathrm{C} 5 \% \mathrm{BCne}$ prezentacje_etc/\%C5 \%BBycie_codzienne_w_czasach_pandemii_-_Wydzia\%C5\%82_Socjologii_UAM_-_WWW.pdf. Dostęp 14.09.2021.

Duszak, Anna, i Norman Fairclough. Krytyczna analiza dyskursu. Universitas, 2008.

Gajda, Stanisław. „Społeczna determinacja nazw własnych tekstów (tytułów)”. Socjolingwistyka, nr 6, 1987, ss.79-89.

Gonera, Marcin. „Funkcjonowanie Kościoła katolickiego w Polsce w czasie pandemii koronawirusa”. com.press, nr 3 (2), 2020, ss. 88-99, ruj.uj.edu.pl/xmlui/bitstream/handle/item/259920/ gonera_funkcjonowanie_kosciola_katolickiego_w_polsce_2020.pdf? sequence $=1 \&$ isAllowed $=\mathrm{y}$. Dostęp 20.09.2021.

Maigret, Éric. Socjologia komunikacji i mediów. Tłum. Iwona Piechnik, Oficyna Naukowa, 2012.

Pawłowska, Ilona. „Nagłówek w sieci. Budowa i funkcja nagłówków prasowych na przykładzie internetowego portalu miejskiego e-sosnowiec.pl”. Rocznik Prasoznawczy, nr 4, 2010, ss. $105-118$.

Sadowska, Agnieszka. „Tytuły prasowe - ich budowa i funkcja”. Acta Universitatis Lodziensis. Folia Litteraria Polonica, nr 9, 2007, ss. 401-413.

Stownik terminologii medialnej, red. Walery Pisarek, Universitas, 2006.

Wilkoń, Aleksander. Typologia odmian językowych współczesnej polszczyzny. Wydawnictwo Uniwersytetu Śląskiego, 1987.

Wodak, Ruth. „Wstęp: badania nad dyskursem - ważne pojęcia i terminy”. Jakościowa analiza dyskursu w naukach społecznych, red. Ruth Wodak i Michał Krzyżanowski, Oficyna Wydawnicza ŁOŚGRAF, 2011, ss. 11-48.

Żydek-Bednarczuk, Urszula. Wprowadzenie do lingwistycznej analizy tekstu. Universitas, 2005. 